Research Article

\title{
Farmers' Perceptions, Awareness and Adoption of Improved Groundnut Varieties in Potwar Plateau of Pakistan
}

\author{
Khalid Mehmood $^{1 *}$,Abdul Rehman ${ }^{2}$ and Ammara Khan ${ }^{1}$
}

${ }^{1}$ Adaptive Research Farm, Sargodha, Directorate General Agriculture (Extension and Adaptive Research), Government of the Punjab, Pakistan; ${ }^{2}$ Directorate of Agriculture Coordination (Farms, Training and Adaptive Research), Punjab, Lahore.

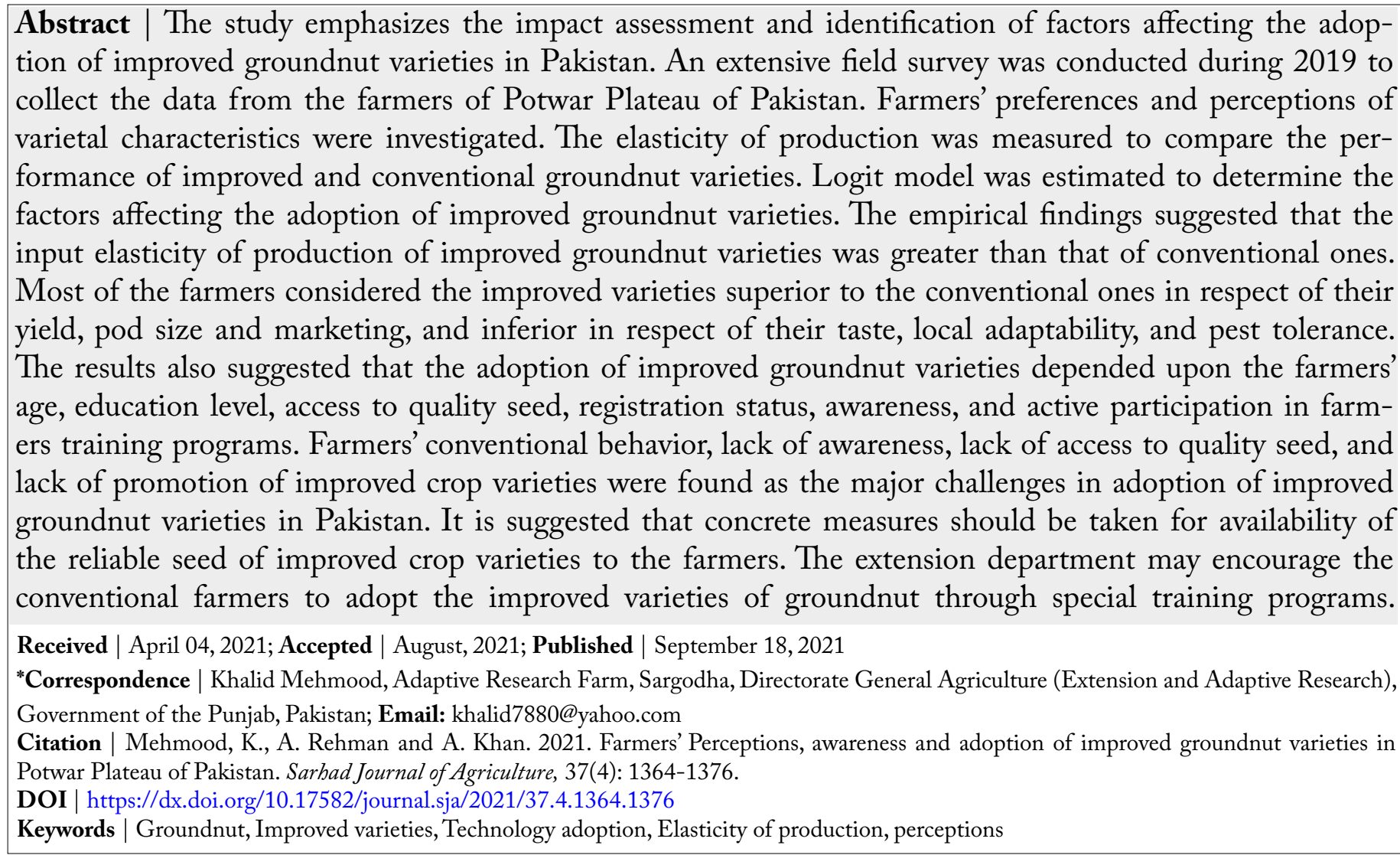

\section{Introduction}

G roundnut (Arachis Hypogea L.) is an important J summer cash crop grown on well-drained sandy or sandy loam soils in Pakistan's marginal lands. It contains $40-50 \%$ oil contents, $22-30 \%$ protein, and $20 \%$ carbohydrates, along with significant dietary contents of vitamin $\mathrm{E}$, iron, zinc, riboflavin, calcium, and thiamine for both human use and livestock feed
(Daudi et al., 2018; Hussain et al., 2020; Hussein et al., 2019; Pasupuleti et al., 2013; Shah et al., 2012). The major groundnut growing areas in Pakistan are Chakwal, Attock and Jhelum in Punjab; Karak and Swabi in NWFP; and Sanghar in Sindh (Malik et al., 2015).

Groundnut crop has large yield gap in Pakistan which is mainly attributed to uncertain weather conditions, 
inadequate application of farm inputs, and persistent cultivation of conventional varieties. Plant breeders have introduced numerous improved, high-yielding, and climate-resilient varieties of groundnut which are enriched with many other preferable characteristics. The evolution of High Yielding Varieties (HYVs) was a key factor towards the green revolution in the early nineties that improved agricultural income worldwide. The adoption of improved varieties of crops can enhance farm production and bring prosperity to the farmers (Daudi et al., 2018; Jelliffe et al., 2018; Konja et al., 2019).

Research institutes in Pakistan, such as National Agricultural Research Center (NARC) Islamabad, Pakistan Agricultural Council (PARC) Islamabad, Barani Agricultural Research Institute (BARI) Chakwal, and Agricultural Research Station Mingora have developed several groundnut varieties, including BARD-699, BARD-479, BARD-92, BARI-89, Chakori, BARI-2000, Golden, SP-2000, SP-2002, BARI-2011 and BARI-2016 (BARI, 2020; Malik et al., 2015; PARC, 2020; Sheirdil et al., 2012). The present recommended varieties in the arid zone of district Chakwal are BARI-2011 and BARI-2016. Numerous field experiments have concluded that the improved groundnut varieties yield higher than the conventional ones (Hussain et al., 2020; Jelliffe et al., 2018; Konja et al., 2019; Mwalongo et al., 2020; Naeem-Ud-Din et al., 2009). However, the adhesion of the local farmers with the conventional varieties, particularly desi variety famous with the name of "No.334" is a major reason for the low productivity of groundnut crop in district Chakwal.

Numerous impediments restrain the adoption of new agricultural technology in farming community. Farmers in developing countries are usually reluctant to grow new crop varieties due to lack of access to seed, high input costs, lack of information, absence of credit facilities, and pest and disease pressure. Literature suggests that farmers' perceptions, socioeconomic characteristics, technological attributes, and human capital are the key drivers to adopt or reject the new crop varieties (Mwalongo et al., 2020; Shiferaw et al., 2010; Tanellari et al., 2014).

Freeman et al. (2002) studied farmers' perceptions regarding the adoption of improved groundnut varieties in Malawi and found that the improved varieties were preferred to the local ones by most of the farm- ers. Using the propensity score matching method, Kassie et al. (2010) showed that improved groundnut varieties significantly enhanced the farmers' incomes and helped to alleviate poverty in rural Uganda. Similar research was conducted by Simtowe et al. (2012) in which the ex-post impact of the adoption of improved groundnut varieties on farmers' consumption expenditure and poverty status was quantified. The study inferred that the adoption of improved groundnut varieties positively influenced the welfare indicators.

Ndjeunga et al. (2008) investigated the extent and determinants of early adoption of the latest groundnut varieties at the groundnut seed project's pilot sites in Mali, Niger and Nigeria. The adoption of new groundnut varieties in Africa lagged due to continuous failure to create awareness among farmers and the provision of seeds and required credit facilities to convert the desired positive demand into effective adoption of new varieties (Shiferaw et al., 2010). Tanellari et al. (2014) determined the factors influencing the farmers' decisions to adopt improved groundnut varieties in Uganda. After conducting a research study in Uganda and Kenya, Thuo et al. (2014) reported that information acquisition and adoption of new varieties were correlated with each other, but information acquisition was exogenous in the adoption model, i.e., both decisions were not jointly determined. Ibrahim et al. (2012) scrutinized the factors determining the adoption of improved groundnut varieties and their likely effects on Northern Ghana's agricultural income.

The literature offers plenty of research focusing on agricultural technology adoption during the past two decades. However, the present study is novel in its nature in the context of Pakistan due to lack of local research on this issue. This paper makes a valuable contribution to the existing literature vis-à-vis the choice of improved agricultural technologies by the farming community and, specifically, understanding the reasons of low adoption rate of improved groundnut varieties in Pakistan.

The objectives of this study are: 1 ) to discuss the socioeconomic characteristics of groundnut farmers in the study area, 2) to study the farmers' perceptions of different varietal traits of groundnut crop, 3) to estimate appropriate production functions and then comparing the input elasticity of production for improved 

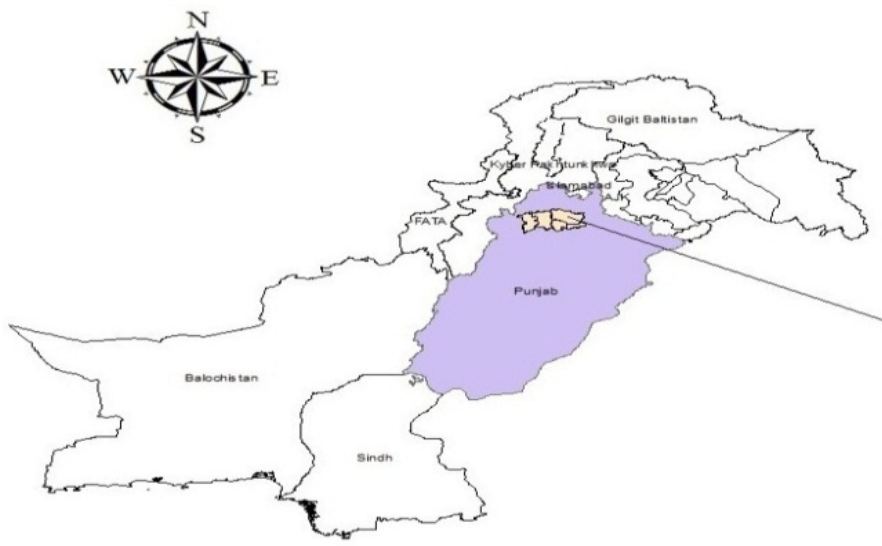

\section{Legend}

Chakwal District Punjab

0

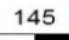

290

580

870

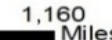

Chakwal District

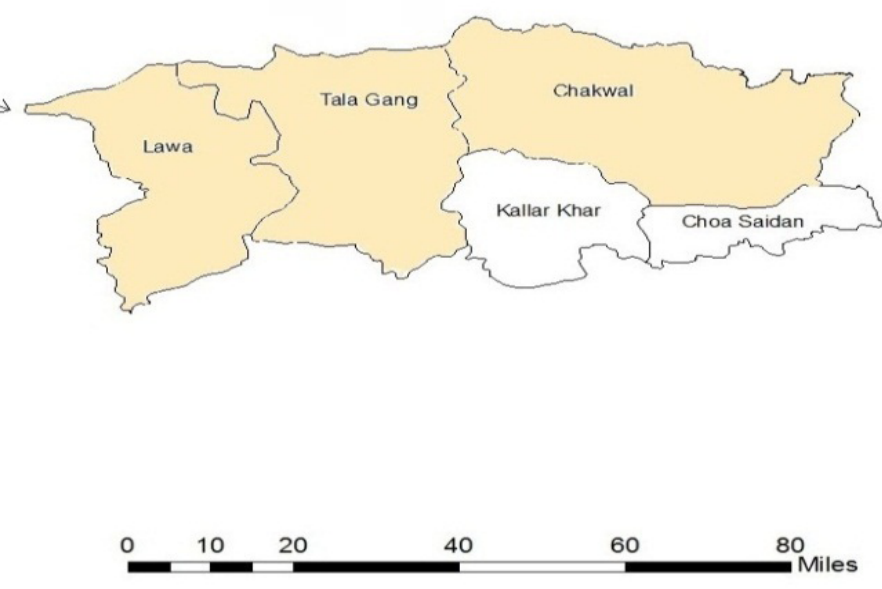

Figure 1: Location map of study area.

and conventional groundnut varieties, 4) to determine the factors affecting the choice of groundnut variety in the study area, and 5) and to suggest appropriate policy recommendations for relevant stakeholders.

\section{Materials and Methods}

\section{Study area and data description}

Study area: The study was conducted in Chakwal district situated in Pothwar Plateau of the Punjab, bordered by Khushab in south, Rawalpindi in northeast, Jhelum in east, Mianwali in west, and Attock in north-west. The Chakwal district area is 6524 square kilometers, which lies between $28^{\circ} 45^{\prime}$ to $30^{\circ} 05^{\prime} \mathrm{N}$ and $72^{\circ} 32^{\prime}$ to $73^{\circ} 13^{\prime} \mathrm{N}$ (Figure 1). According to the 2017 census, Chakwal has about 1.496 million population (GoP, 2017). The district is located in arid zone, and local farming relies on rainfall. Some farmers also use tube wells and mini dams to irrigate their farmlands on the small scale. Chakwal is divided into five tehsils, namely Chakwal, Kallar Kahar, Talagang, Lawa, and Choa Saidan Shah. The barani zone comprises of about 3 million hectares out of a total of 11.4 million hectares under cultivation in Punjab, which is about $30 \%$ of the whole Punjab. It is further characterized by different ecological zones depending upon rainfall pattern. A diversified cropping system prevails in the rainfed area of Chakwal district.

Data collection: The study used primary data to achieve the research objectives. For data collection, an extensive field survey was conducted through face-to- face interviews with farmers. The technique of faceto-face interviews allows the interviewer to respond to the interviewees' attitudes and better understand their reasoning for the questions (Marshall and Rossman, 2014).

A semi-structured questionnaire was used to collect the data, which consisted of three main parts. The first part covered the questions related to the respondents' socioeconomic characteristics. The second part consisted of questions about the use of inputs and the crop yield. The third part contained the questions about farmers' preferences and perceptions regarding the different traits of improved and local varieties of groundnut. It included open-ended questions and the questions with predefined preference ratings. The preference rating was obtained on a 3-points Likert scale in which farmers were to choose whether the particular trait of the conventional (or improved) groundnut variety was 1) good, 2) normal, or 3) bad to them. The subject traits included taste, pod size, marketability, maturity duration, yield, adaptability, pest tolerance, and drought tolerance of the conventional and improved varieties.

The questionnaire was pre-tested in the field to make necessary modifications. The data collection was performed through trained enumerators. Before starting the interview, verbal consent was obtained from every respondent.

A stratified (multistage) random sampling technique December 2021 | Volume 37 | Issue 4 | Page 1366 
was used to select the sample for data collection. At the first stage, Chakwal district was selected as the sampling frame that is one of the potential groundnut-producing regions of Punjab (PARC, 2020). At the second stage, three strata, i.e., administrative units/ tehsils of Chakwal district, were selected as the study area: (1) Chakwal, (2) Talagang, and (3) Lawa. The remaining two tehsils, Kallar Kahar, and Choa Saidan Shah were excluded due to their meager share in total groundnut production. At third stage, six villages were randomly selected from each stratum. Having different populations of each village, the selected sample size was proportional to each village's population size. Proportional allocation allows the proportionate distribution of sampled data among different strata (Rajpar et al., 2019). The sample size at village level was selected, using the following formula:

$$
n_{i}=n \cdot \frac{N i}{N} \text { for } i=1,2.3, \ldots, 6
$$

Where;

$n_{i}$ : Sample size for $\mathrm{i}^{\text {th }}$ stratum (the village in this case); $n$ : Sample size for a tehsil (120 in this case); $N_{i}$ : Total number of households (farmers) in the $\mathrm{i}^{\text {th }}$ stratum; $N$ : Sum of households in all 6 strata (also total population of 6 villages).

A random sample of 120 respondents was selected from each tehsil (with six villages). Repeating the same procedure for three tehsils, a total sample of 360 respondents was extracted from 18 villages of district Chakwal.

After data screening, 16 observations were dropped due to insufficient or asymmetric information (outliers), and the remaining sample of 344 observations was analyzed. The data were analyzed using R-software v. 4.0.0 (Team, 2020).

\section{Econometric modeling}

Production functions and elasticity of production: Production function measures the technical relationship between input and output, whereas, elasticity of production measures the responsiveness of output to the input (Debertin, 2012). The study estimated two production functions and compared the input elasticities of production for local and improved groundnut varieties. This approach enabled us to determine which type of varieties can perform better by spending more on the farm inputs. The elasticity approach has not been used in previous studies on the course of varietal choice of groundnut especially in the context of Pakistan.

To estimate the elasticity of production, Cobb Douglas type of Production Function (CDPF) and Generalized Power Production Function (GPPF) were used in this study. GPPF is a generalized form of transcendental production function (Halter et al., 1957) with the de Janvry modification (de Janvry, 1972). The CDPF and GPPF in specific forms are given below in Equation 1 and 2, respectively.

$$
\begin{gathered}
y=A x_{1}{ }^{\alpha_{1}} x_{2}{ }^{\alpha_{2}} \ldots x_{n}{ }^{\alpha_{n}} \\
y=A x_{1}{ }^{\alpha_{1}} x_{2}{ }^{\alpha_{2}} \ldots x_{n}{ }^{\alpha_{n}} e^{\beta_{1} x_{1}+\beta_{2} x_{2}+\ldots+\beta_{n-1} x_{n-1}}
\end{gathered}
$$

\section{Where;}

$y$ is the per hectare (average) yield of groundnut crop, $A$ is the constant term and $\mathrm{x}_{i}$ is the $\mathrm{i}^{\text {th }}$ explanatory variable. The term ' $n-1$ ' in Equation 2 implies that there is one fewer variable in the exponent of the base of natural logarithm $(e)$, which is average annual income of the respondents. Since, it is understood that annual income does not hold the law of diminishing marginal returns, so inclusion of this variable in the exponent of ' $e$ ' makes no sense. The Model 2 included only the linear form of income variable in the product of ' $x_{i}$ '.

Inputs $\left(x_{i}\right)$ in the aforementioned econometric models are in the forms of money spent for $\mathrm{i}^{\text {th }}$ input, rather than their physical quantities. However, the output $(y)$ is in the form of an average physical quantity. The Equations $1 \& 2$ can be linearly transformed into equation 3 and 4, respectively in order to apply the ordinary least squares technique (Griffiths et al., 1993; Gujarati, 2009).

$\operatorname{Ln} y=\operatorname{Ln} A+\alpha_{1} \operatorname{Lnx}_{1}+\alpha_{2} \operatorname{Lnx}_{2}+\cdots+\alpha_{n} \operatorname{Ln} x_{n}$
$\operatorname{Ln} y=\operatorname{Ln} A+\alpha_{1} \operatorname{Ln} x_{1}+\alpha_{2} \operatorname{Lnx}_{2}+\cdots+\alpha_{n} \operatorname{Ln} x_{n}+\beta_{1} x_{1}+\beta_{2} x_{2}+\cdots+\beta_{n-1} x_{n-}$

The performance of improved and local varieties was evaluated by measuring the respective input elasticities of production using CDPF and GPPF, separately for each group. The description of variables is given below:

$\mathrm{y}$ : Average yield ( $\mathrm{Kg}$ per hectare).

$\mathrm{x}_{1}$ : Land preparation cost ('000' PKR per hectare).

$\mathrm{x}_{2}$ : Seed cost ('000' PKR per hectare).

$\mathrm{x}_{3}$ : Fertilizer cost ('000' PKR per hectare). 
$\mathrm{x}_{4}$ : Hoeing cost ('000' PKR per hectare).

$\mathrm{x}_{5}$ : Annual income (Million PKR).

For convenience, rather than using the number of units of each input individually as explanatory variables, we aggregated the input costs group-wise to capture the overall effect of each group of inputs. Land preparation cost involves the cost of land leveling, planking, ploughing, and tillage operations. Seed cost includes the cost incurred by purchase and transportation of seed. Fertilizer cost includes the cost of Urea, DAP, Nitrophos, farmyard manure, and other fertilizers used in the production of groundnut. Hoeing cost is the amount spent on manual hoeing.

The coefficient $\alpha_{i}$ of CDPF in Model 3 indicates the elasticity of production for $i^{\text {th }}$ input. However, in Model 4, the elasticity of production is some function of respective input. The elasticity of production $(\eta)$ for inputs is constant for CDPF but variable for GPPF as given in equations below:

$$
\begin{gathered}
\eta_{C D P F_{i}}=M P P x_{i} / A P P x_{i}=\alpha_{i} \\
\eta_{G P P F_{i}}=M P P x_{i} / A P P x_{i}=\alpha_{i}+\beta_{i} x_{i}
\end{gathered}
$$

In above equations, $\eta_{C D P F i}$ is the elasticity of production for $i^{\text {th }}$ input for CDPF and $\eta_{G P P F i}$ is the elasticity of production for $\mathrm{i}^{\text {th }}$ input for GPPF. $M P P x_{i}$ and $A P P x_{i}$ are the marginal physical product and average physical product for $\mathrm{i}^{\text {th }}$ input, respectively.

Logit model: Logit model was employed to determine the factors affecting the choice of groundnut variety in study area. Numerous studies used Logit and Probit models to determine the factors affecting the adoption of improved groundnut varieties, especially in African countries (Ibrahim et al., 2012; Mwalongo et al., 2020; Ndjeunga et al., 2008; Shiferaw et al., 2010; Tanellari et al., 2014; Thuo et al., 2014). Type of variety grown was the dichotomous dependent variable with value of ' 1 ' for improved variety and ' 0 ' otherwise. The parameters were estimated through the Maximum-Likelihood method for the individual level data (Aldrich et al., 1984; DeMaris, 1992). The general form of logistic regression model, is given as under:

$$
\mathrm{L}_{i}=\ln \left(\frac{\mathrm{p}_{i}}{1-\mathrm{p}_{i}}\right)=\beta_{0}+\beta_{1} \mathrm{X}_{1}+\ldots \ldots \ldots+\beta_{i} \mathrm{X}_{i}
$$

The cumulative logistic distribution function is given as:

$$
\mathrm{P}_{i}=E\left(Y=1 \mid \mathrm{X}_{i}\right)=\frac{1}{1+e^{-\left(\beta_{0}+\beta_{1} X_{i}+\ldots \ldots+\beta_{i} X_{i}\right)}}=\frac{e^{z_{i}}}{1+e^{z_{i}}}
$$

Where,

$\mathrm{L}_{i}$ : Logit i.e., natural $\log$ of the odds ratio; $\mathrm{P}_{i}$ : Probability that farmers would adopt the improved groundnut variety; $1-\mathrm{P}_{i}$ : Probability that farmer would grow the local groundnut variety; $\beta_{i}: \mathrm{i}^{\text {th }}$ Parameter of the model to be estimated; $Z_{i}=\beta_{0}+\beta_{1} X_{1}+\ldots \ldots \ldots+\beta_{i} X_{i}$

The independent variables used in the model include age, education, income, farm size, basic facilities in the area, access to seed, farmers' registration status, awareness, taste consciousness, and participation in Farmers Training Programs (FTPs). These variables were related to the farmers' perceptions, socioeconomic characteristics, and awareness about the improved groundnut varieties and defined as:

Variety $($ Dependent $)=1$ if improved variety is grown, 0 , otherwise.

Age $=$ Farmer's age in years .

Education $=$ Farmers' years of schooling.

Income $=$ Farmer's annual income in Million PKR.

Farm size $=$ Operational landholding size in hectares . Basic facilities $(D)=1$ if there is sufficientinfrastructure for health, education etc., in the area, 0 , otherwise.

Access to seed (D) $=1$ if easy access to the seed of improved varieties, 0 , otherwise.

Farmer's registration (D) $=1$ if farmer is registered with government of Punjab, 0, otherwise.

Awareness (D) = 1 if farmers is aware of improved production technology, 0 , otherwise.

Taste consciousness $(\mathrm{D})=1$ if the farmer is taste conscious for peanut, 0 otherwise.

FTPs (D) $=1$ if farmer has participated in FTPs at least twice in previous two

years, 0 , otherwise.

To test the null hypothesis that the slope of all coefficients is simultaneously equal to zero, the equivalent of the F-test is the Likelihood Ratio (LR) statistic in Logit model; that follows the $X^{2}$ distribution with degree of freedom equal to the number of explanatory variables. Another comparatively simple measure of goodness of fit is the count $-\mathrm{R}^{2}$, defined as:

$$
\text { Count } \mathrm{R}^{2}=\frac{\text { Number of correct predictions }}{\text { Total number of observations }}
$$


Table 1: Socioeconomic profile of the farmers in study area.

\begin{tabular}{lllll} 
Socioeconomic Characteristic & Total $(\mathbf{N}=\mathbf{3 4 4})$ & Adopters $(\mathbf{N}=\mathbf{8 0})$ & Non-Adopters $(\mathbf{N}=\mathbf{2 6 4})$ & t-Statistic \\
Age (years) & 42.16 & 37.89 & 43.45 & $-3.13^{* * * *}$ \\
Education (years) & 9.60 & 10.89 & 9.21 & $5.03^{\text {**** }}$ \\
Family size (No.) & 7.93 & 6.01 & 8.52 & $-9.87^{* * * *}$ \\
\hline Joint family system (\%) & 42 & 10 & 52 & $-9.08^{* * * *}$ \\
Operational farm size (ha) & 14.98 & 10.86 & 16.23 & $-4.7^{* * * *}$ \\
Groundnut area (ha) & 4.60 & 0.91 & 5.13 & $-3.95^{* * *}$ \\
Annual income (million PKR) & 1.808 & 1.304 & 1.960 & $-4.66^{* * *}$ \\
Farming as main occupation (\%) & 89 & 95 & 85 & 1.04 \\
Tractor owned (\%) & 72 & 80 & 70 & $1.94^{*}$ \\
Participants of FTPs (\%) & 46 & 90 & 33 & $12.72^{* * * *}$ \\
Android phone owned (\%) & 41 & 52 & 35 & $1.79^{*}$ \\
Awareness of technology (\%) & 35 & 85 & 19 & $23.98^{* * *}$ \\
Easy access to seed (\%) & 24 & 72 & 9 & $11.90^{* * *}$ \\
Registered farmers (\%) & 62 & 65 & 61 & 0.71 \\
Chakwal tehsil (No.) & 95 & 22 & 73 & - \\
Talagang tehsil (No.) & 115 & 24 & 91 & - \\
Lawa tehsil (No.) & 134 & 30 & 104 & -
\end{tabular}

Source: Author's Own Calculations

The correct predictions are those for which the residuals of the model are greater than -0.5 and less than +0.5 .

\section{Results and Discussion}

\section{Socioeconomic profile of sample farmers}

Understanding the socio-economic profile of respondents is very important in the studies based on survey data. After data screening, we had a total of 95 observations from tehsil Chakwal with 23\% adopters of improved varieties and $77 \%$ non-adopters; 115 observations from tehsil Talagang with $21 \%$ adopters, and 79\% non-adopters; and 134 observations from tehsil Lawa with 22\% adopters and 78\% non-adopters. The distribution of data concerning the adaptability of improved varieties is almost equal along all the three cross-sections of study area.

Table 1 numerically summarizes the socioeconomic characteristics of the sample respondents in study area. The results revealed that the adopters of improved groundnut varieties were younger and more educated than the non-adopters. It shows the innovative attitudes of the adopters of new production technology. The adopters have a smaller family size and larger size of landholding as compared to the non-adopters. The average area under improved varieties of groundnut was smaller than that of local varieties. The adop- ters have lower annual income as compared to the non-adopters due to their small landholdings. The adoption rate is higher for the farmers having agriculture as a primary occupation in contrast to those having farming as a secondary occupation. On an average, $80 \%$ of the adopters of improved varieties and $70 \%$ of the non-adopters owned a tractor. The characteristics of farmers' awareness i.e., participation in FTPs, possessing an android cell phone, awareness of new groundnut production technology, and farmers' registration with the government indicated that the higher the awareness of the farmers, the more likely they were to adopt the improved groundnut varieties. On the average, $72 \%$ of the adopters and only $9 \%$ of the non-adopters had easy access to the seed of improved varieties.

\section{Results of production functions for groundnut varieties}

Table 2 presents the technical relationship between input and output in the form of CDPF and GPPF. For pooled data, CDPF shows that the expenditures incurred on land preparation, seed, fertilizer, and hoeing are directly proportional to the productivity of the groundnut crop. The results of second model (GPPF) with pooled data show that the seed cost experiences diminishing marginal returns, whereas the costs of fertilizer and manual hoeing reveal the contrary phenomenon. The latter may be due to the reason that all the respondents, on average, spent less on fertilizer 
Table 2: Production functions for conventional, improved and pooled varieties.

\begin{tabular}{|c|c|c|c|c|c|c|}
\hline \multirow[t]{2}{*}{ Variable } & \multicolumn{2}{|l|}{ Pooled } & \multicolumn{2}{|c|}{ Conventional varieties } & \multicolumn{2}{|c|}{ Improved varieties } \\
\hline & CDPF & GPPF & CDPF & GPPF & $\mathrm{CDPF}$ & GPPF \\
\hline \multirow[t]{2}{*}{ Land preparation cost } & - & 0.005 & - & $0.019^{*}$ & - & $-0.258^{* * *}$ \\
\hline & & $(0.013)$ & & $(0.01)$ & & $(0.037)$ \\
\hline \multirow[t]{2}{*}{ Seed cost } & - & $0.087^{* * * *}$ & - & $0.032^{* *}$ & - & $0.118^{*}$ \\
\hline & & $(0.02)$ & & $(0.015)$ & & $(0.061)$ \\
\hline \multirow[t]{2}{*}{ Fertilizer cost } & - & $-0.024^{*}$ & - & -0.016 & - & $-0.100^{* * *}$ \\
\hline & & $(0.012)$ & & $(0.01)$ & & $(0.031)$ \\
\hline \multirow[t]{2}{*}{ Manual hoeing cost } & - & $-0.542^{* * *}$ & - & $-0.750^{* * *}$ & - & $0.645^{*}$ \\
\hline & & $(0.04)$ & & $(0.048)$ & & $(0.329)$ \\
\hline \multirow[t]{2}{*}{ Ln (Land preparation cost) } & $0.145^{* * * *}$ & -0.008 & 0.045 & $-0.265^{* *}$ & $0.140^{* *}$ & $4.169^{* * * *}$ \\
\hline & $(0.051)$ & $(0.179)$ & $(0.052)$ & $(0.133)$ & $(0.056)$ & $(0.589)$ \\
\hline \multirow[t]{2}{*}{ Ln (Seed cost) } & $0.782^{* * * *}$ & $-0.853^{* * *}$ & 0.098 & $-0.652^{* * *}$ & $0.310^{\text {***** }}$ & $-2.018^{*}$ \\
\hline & $(0.08)$ & $(0.324)$ & $(0.092)$ & $(0.238)$ & $(0.108)$ & (1.118) \\
\hline \multirow[t]{2}{*}{ Ln (Fertilizer cost) } & $0.149^{* * * *}$ & $0.157^{* * * *}$ & $0.053^{* *}$ & $0.084^{* *}$ & $0.112^{* * * *}$ & $0.704^{* * * *}$ \\
\hline & $(0.028)$ & $(0.053)$ & $(0.027)$ & $(0.041)$ & $(0.037)$ & $(0.139)$ \\
\hline \multirow[t]{2}{*}{ Ln (Manual hoeing cost) } & $1.222^{* * * *}$ & $4.538^{* * * * *}$ & $2.427^{* * * * *}$ & $6.292^{* * * *}$ & $2.650^{* * k * k}$ & -3.535 \\
\hline & $(0.052)$ & $(0.248)$ & $(0.102)$ & $(0.248)$ & $(0.226)$ & $(3.082)$ \\
\hline \multirow[t]{2}{*}{ Ln (Annual Income) } & -0.009 & $-0.028^{* * k}$ & $0.042^{\text {**** }}$ & $0.020^{*}$ & $-0.106^{* * *}$ & $-0.033^{*}$ \\
\hline & $(0.017)$ & $(0.014)$ & $(0.015)$ & $(0.011)$ & $(0.02)$ & $(0.018)$ \\
\hline \multirow[t]{2}{*}{ Ln (Intercept) } & $2.031^{* * * *}$ & $3.273^{* * * *}$ & $2.237^{* * * *}$ & $2.204^{* * * *}$ & $0.870^{* *}$ & 5.461 \\
\hline & $(0.236)$ & $(0.63)$ & $(0.233)$ & $(0.453)$ & $(0.384)$ & $(4.284)$ \\
\hline Adjusted $\mathrm{R}^{2}$ & 0.847 & 0.905 & 0.880 & 0.950 & 0.878 & 0.941 \\
\hline F-Statistic & $381.600^{* * * *}$ & $363.900^{\text {**** }}$ & $388.400^{\text {*** }}$ & $560.100^{* * * *}$ & $114.900^{\text {**** }}$ & $140.400^{* * * *}$ \\
\hline No of observations & 344 & 344 & 264 & 264 & 80 & 80 \\
\hline AIC & 114.185 & -45.038 & -0.767 & -228.762 & -100.126 & -154.245 \\
\hline BIC & 141.069 & -2.791 & 24.264 & -189.427 & -83.452 & -128.043 \\
\hline
\end{tabular}

Note: S.E reported under the coefficients in parenthesis. Significance Codes: ${ }^{(* * *)}=0.01^{(* *)}=0.05^{(*)}=0.1$

and manual hoeing as compared to the recommended or output maximizing (optimum) levels of these inputs. The annual income negatively influenced the groundnut productivity for pooled sample.

For the adopters of local varieties, CDPF, shows that the annual income, outlays for fertilizer and manual hoeing significantly and positively influenced the groundnut productivity, whereas GPPF for local varieties shows almost the same results as GPPF with pooled data with the exception of the annual income of the farmers.

In the case of adopters of improved groundnut varieties, CDPF shows that the outlays for land preparation, seed, fertilizer, and manual hoeing significantly and positively influenced the groundnut productivity; whereas GPPF shows that the expenditure incurred on seed and hoeing operation retained diminishing marginal productivity. However, the costs of land preparation and fertilizer application experienced increasing marginal productivity with respect to the corresponding inputs. It may also be attributed to the sub-optimal usage of fertilizer and tillage practices by the farmers. The test statistics i.e., F-value, $\mathrm{R}^{2}, \mathrm{AIC}$, and BIC show that the models are improved while switching from CDPF to GPPF.

Input elasticity of production for groundnut varieties The results of input elasticity of production for groundnut varieties are presented in Table 3, which shows that improved varieties are comparatively more elastic - in terms of per hectare yield - towards the use of inputs such as land preparation, seed, fertilizer, and tillage operations. For CDPF specifically, the results can be interpreted in the way that, an incremental rupee spent on an input adds more to the productivity of groundnut crop in case of improved 
Table 3: Elasticities of production for improved and conventional varieties of groundnut.

\begin{tabular}{|c|c|c|c|c|c|c|}
\hline \multirow[t]{2}{*}{ Variable } & \multicolumn{2}{|l|}{ CDPF } & \multirow{2}{*}{$\begin{array}{l}\text { Comparison } \\
\eta_{I}>\eta_{C}\end{array}$} & \multicolumn{2}{|l|}{ GPPF } & \multirow{2}{*}{$\begin{array}{l}\text { Comparison } \\
\eta_{I}>\eta_{C}\end{array}$} \\
\hline & $\eta_{I}$ & $\eta_{C}$ & & $\eta_{I}$ & $\eta_{C}$ & \\
\hline $\mathrm{X}_{1}$ : Land prep. Cost & 0.140 & 0.045 & $\eta_{I}>\eta_{C}$ & $-0.258 X_{1}+4.169$ & $0.019 X_{1}-0.265$ & $\eta_{I}>\eta_{C}$ for $\mathrm{X}_{1}<16.01$ \\
\hline $\mathrm{X}_{2}:$ Seed cost & 0.310 & 0.098 & $\eta_{I}>\eta_{C}$ & $0.118 X_{2}-2.018$ & $0.032 X_{2}-0.652$ & $\eta_{I}>\eta_{C}$ for $X_{2}<15.88$ \\
\hline $\mathrm{X}_{3}:$ Fertilizer cost & 0.112 & 0.053 & $\eta_{I}>\eta_{C}$ & $-0.1 X_{3}+0.704$ & $-0.016 \mathrm{X}_{3}+0.084$ & $\eta_{I}>\eta_{G}$ for $X_{3}<7.38$ \\
\hline $\mathrm{X}_{4}:$ Hoeing cost & 2.650 & 2.427 & $\eta_{I}>\eta_{C}$ & $0.645 X_{4}-3.535$ & $-0.75 X_{4}+6.292$ & $\eta_{I}>\eta_{C}$ for $X_{4}<7.04$ \\
\hline $\mathrm{X}_{5}:$ Annual Income & -0.106 & 0.042 & $\eta_{I}>\eta_{C}$ & $-0.033 X_{5}$ & $0.02 \mathrm{X}_{5}$ & $\eta_{I}>\eta_{C}$ for $X_{5}<0$ \\
\hline
\end{tabular}

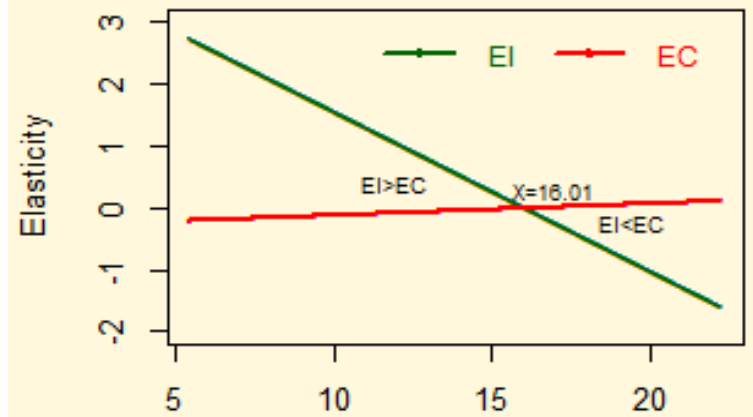

Land preparation cost '000' PKR

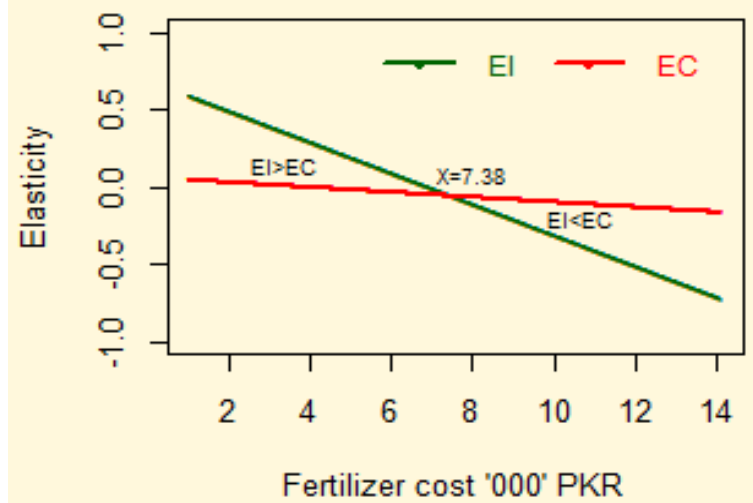

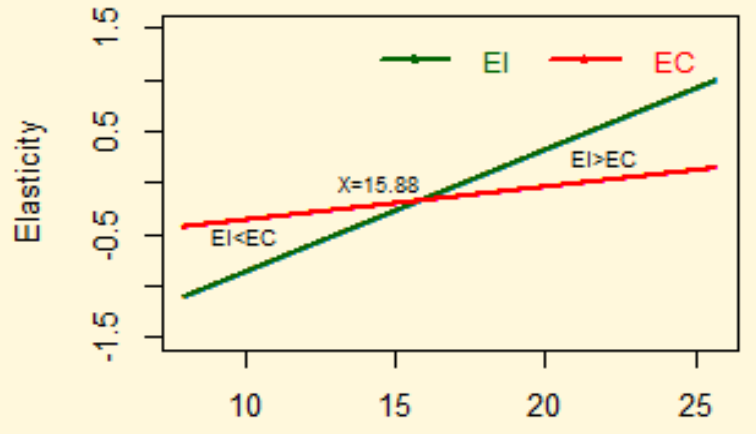

Seed cost '000' PKR

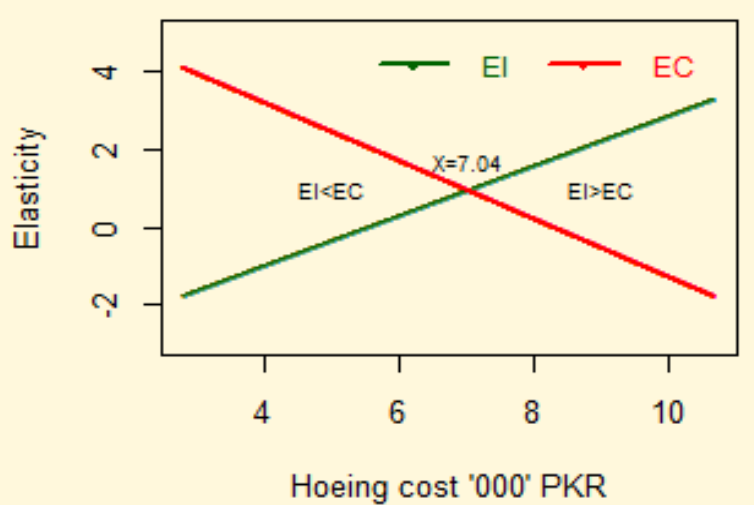

Figure 2: Input Elasticities for Improved (EI) and Conventional (EC) Varieties of Groundnut for GPPF.

varieties as compared to that of conventional ones. The elasticity of production can also be termed as the ratio of Marginal Physical Product (MPP) to Average Physical Product (APP) (Debertin, 2012). The results suggested that the ratio of MPP to APP is comparatively larger for improved varieties than the conventional ones.

The elasticity of production derived from GPPF is variable and exists in linear equation form (i.e., $a X_{i}+$ $b$ ) which depends on the cost of corresponding input. In the case of GPPF, the last column of Table 3 describes the threshold (maximum or minimum) cost levels of each input where the elasticity of production for improved varieties $\left(\eta_{I}\right)$ is greater or smaller than that for conventional varieties $\left(\eta_{C}\right)$. For land preparation $\left(X_{1}\right)$ specifically, $\eta_{I}$ is greater than the $\eta_{C}$ at any level below the land preparation cost of Rs. 16010 per hectare. For $X_{2}, \eta_{I}$ is greater than the $\eta_{C}$ at any level where the seed cost is less than Rs. 15880 per hectare. For $\mathrm{X}_{3}, \eta_{I}$ is greater than the $\eta_{C}$ at any level below the fertilizer cost of Rs. 7380 per hectare. Similarly, within the hoeing cost of Rs. 7040, the yield of improved varieties is more elastic toward hoeing operation as compared to that of conventional ones. The elasticity of an input's cost in GPPF is a straight line for both improved and local varieties as shown in Figure 2. There is a specific threshold level of each input where the elasticity is equal for both the improved and conventional groundnut varieties. 
Table 4: Factors affecting the choice of groundnut varieties: Results of the logit model.

$\begin{array}{lllll}\text { Variable } & \text { Logit Estimate } & \text { Odds Ratio } & \text { Std. Err } & \text { Marginal Effects } \\ \text { (Intercept) } & -8.6102^{* * *} & 0.0002 & 1.8747 & - \\ \text { Age } & 0.0416^{*} & 1.0424 & 0.0212 & 0.0025 \\ \text { Education } & 0.1689^{* *} & 1.1840 & 0.0850 & 0.0102 \\ \text { Income } & -0.1286 & 0.8793 & 0.2378 & -0.0078 \\ \text { Farm Size } & -0.0774^{* *} & 0.9255 & 0.0349 & -0.0047 \\ \text { Basic facilities in area (D) } & 0.9891^{*} & 2.6889 & 0.5919 & 0.0597 \\ \text { Access to seed (D) } & 3.0156^{* * *} & 20.4012 & 0.5199 & 0.1820 \\ \text { Farmers' registration (D) } & 2.1293^{* * *} & 8.4093 & 0.6834 & 0.1285 \\ \text { Awareness of varieties (D) } & 2.7040^{* * *} & 14.9389 & 0.5848 & 0.1632 \\ \text { Taste consciousness (D) } & -1.3330^{* *} & 0.2637 & 0.6634 & -0.0805 \\ \text { Participation in FTPs (D) } & 1.7355^{* * *} & 5.6720 & 0.6518 & 0.1048\end{array}$

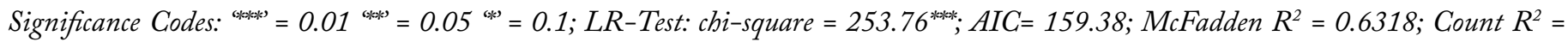
0.7965

Farmers' preferences and perceptions of the varietal characteristics

The improved and conventional varieties of groundnut differ in several characteristics which influence their adoption potential (Mwalongo et al., 2020; Shiferaw et al., 2010). Figure 3 shows the distribution of farmers according to their perceptions regarding the traits of improved and local varieties of groundnut. According to the survey results, most of the farmers perceived the local groundnut varieties as normal in terms of yield, marketability, and maturity duration; whereas good in terms of taste, local adaptability, pest resistance and drought tolerance. Small pod size and less marketability are the major characteristics of local varieties which are disliked by most farmers. The results indicate that the taste-conscious farmers mostly prefer to grow local varieties of groundnut in study area. Based on overall performance, about 33\%, $47 \%$, and $20 \%$ of the farmers rated the conventional groundnut varieties as good, normal, and bad, respectively.

On the other hand, most of the farmers perceive that improved groundnut varieties are good in yield, pod size, and marketability. However, many farmers are not satisfied with the taste, local adaptability, pest and drought tolerance of the improved groundnut varieties. They are of the view that improved varieties are more susceptible to diseases and insect attacks as compared to the local varieties. The large grain size and the excellent marketability of improved groundnut varieties are the major characteristics liked and preferred by most of the groundnut farmers. As per overall performance, $35 \%, 39 \%$, and $26 \%$ of the respondents rated the improved groundnut varieties as good, normal, and bad, respectively. According to the survey, most of the farmers (65\%) preferred to grow the local varieties. So, the study results infer that the farmers' perceptions and preferences play key role in the adoption of improved groundnut varieties (Mwalongo et al., 2020; Ndjeunga et al., 2008).

\section{Factors affecting the choice of groundnut variety}

Logit model was estimated to determine the factors affecting the adoption of improved groundnut varieties. The results are presented in Table 4, which shows that farmers' age, education, basic facilities, accessibility to improved seed, registration status, awareness of varieties, and their participation in FTPs significantly increase the likelihood of adoption of improved groundnut varieties. On the other hand, taste consciousness and farm size significantly decrease the probability of choosing the improved varieties. Interpreting empirically, each logit estimate of the model is a partial slope coefficient which measures the change in logit because of a unit change in the value of a given regressor. Thus, the age coefficient 0.04 implies that if the farmer's age increases by one year, the estimated logit increases by about 0.04 units in favor of opting for the improved variety, other things remaining the same. The LR statistic is statistically significant which reveals that overall, the regressors included in the model significantly affect the choice of groundnut variety. 


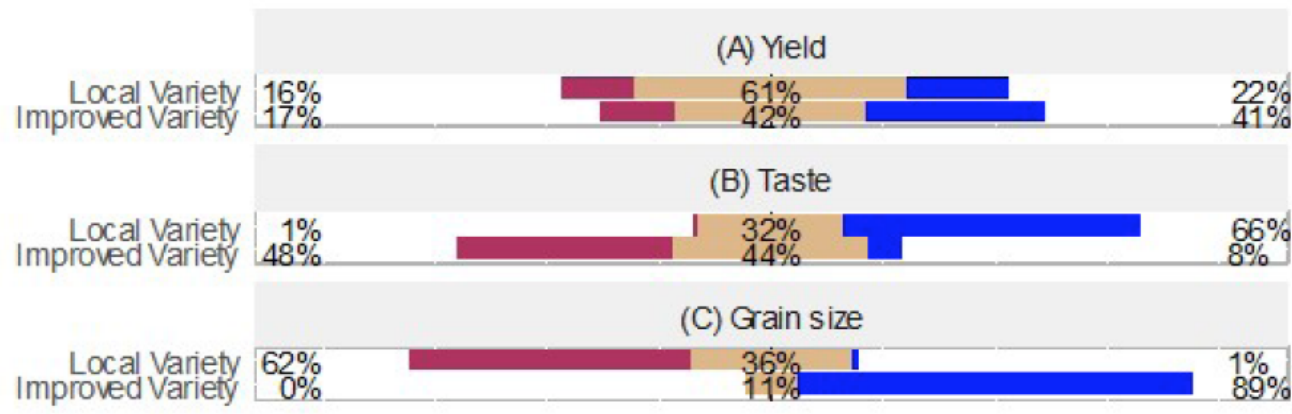

(D) Marketability

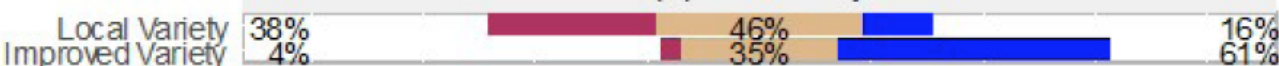

(E) Duration of maturity

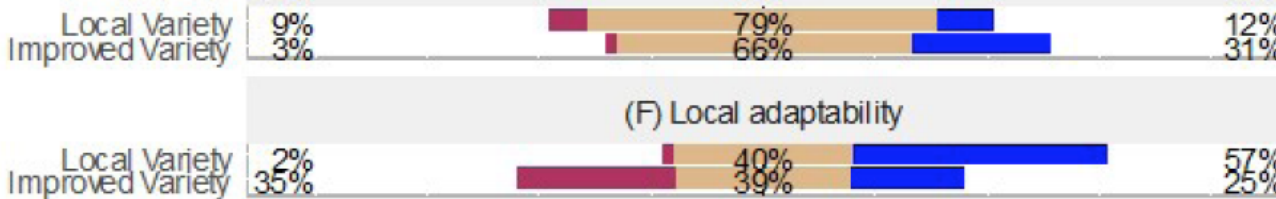

(G) Pest tolerance

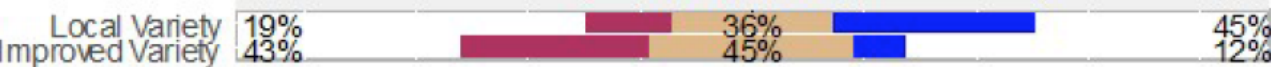

(H) Drought tolerance

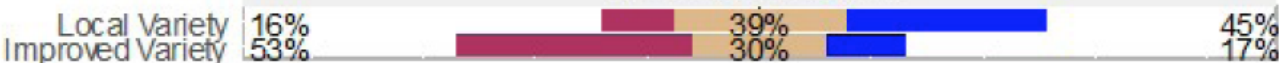

(I) Overall performance

\begin{tabular}{c|cccc} 
Local Variety & $21 \%$ & & $46 \%$ & \\
Improved Variety & $25 \%$ & $39 \%$ & $32 \%$ \\
& 100 & 50 & 0 & 50 \\
& & Percentage & & 100
\end{tabular}

Response Bad Normal Good

Figure 3: Farmers'perceptions of improved and local varieties.

The antilog of a slope coefficient yields an odds ratio that provides a more meaningful interpretation. Thus, taking the antilog of the farmers' registration coefficient of 2.13 , we get $8.41\left(\approx \mathrm{e}^{2.13}\right)$, which implies that the farmers registered with the government are more than 8 times as likely to adopt an improved groundnut variety as compared to non-registered farmers, ceteris paribus.

For simplicity, the results can also be interpreted in terms of marginal effects. Marginal effect of the age (0.0025) suggests that if farmer's age goes up by one year, the probability of choosing an improved groundnut variety rises by $0.25 \%$. Similarly, if farmer's education goes up by unit level (one year), the probability of choosing an improved groundnut variety goes up by $1.02 \%$. The greater marginal effect suggests a stronger positive impact of education level on the adoption of improved varieties as compared to the farmers' age. The educated farmers are more inclined December 2021 | Volume 37 | Issue 4 | Page 1373 towards the adoption of new production technology. If farmer's annual income goes up by a thousand $\mathrm{Pa}-$ kistani rupees, the probability of choosing improved groundnut variety goes down by $0.78 \%$. Farm size is also negatively related to the probability of choosing improved variety because larger the farm size, the more challenging will be to manage it, and ultimately, less attention could be devoted to the adoption of new technology.

The farmers of developed areas, having the availability of basic facilities (education, livelihood, health etc.,), are $6 \%$ more likely to adopt the improved varieties of groundnut than those living in the backward areas. The farmers of progressive areas have more awareness $\&$ willingness to adopt new technologies due to their innovative attitude and better education levels (Ibrahim et al., 2012; Ndjeunga et al., 2008). Similarly, the farmers registered with the governResearchers 
ment, having easy access to improved seed varieties and aware of groundnut varieties are 12.8\%, 18.2\%, and $16.3 \%$ more likely to adopt improved varieties as compared to their counterparts, respectively. From the last few years, the government of Punjab has started the farmers' registration program which facilitates the farmers in multiple ways such as e-credit schemes, agricultural loan services, weather forecast transmission, updates regarding the latest agricultural technologies through smartphones and several other services. The registered farmers remain connected with the agricultural information network system, and they are more aware of farming technologies and new varieties of crops. The study results are in accordance with the previous literature, such as the adoption of improved groundnut varieties in Africa was impeded by the continuous failure in creating awareness among the farmers along with the non-provision of improved seeds and credit facilities (Shiferaw et al., 2010). Thuo et al. (2014) also found that the information acquisition or awareness was positively correlated to the adoption of improved varieties in Uganda and Kenya.

Taste-conscious farmers preferred the conventional groundnut varieties for their better taste. Hence, they are $8 \%$ less likely to adopt improved groundnut varieties as compared to their counterparts. The participants of FTPs organized by Agriculture Extension Department are $10.5 \%$ more likely to grow improved varieties. It indicates that the FTPs greatly help in creating awareness and motivating the farmers to adopt new agricultural technologies in agribusiness. The study results support the findings of previous studies such as Ndjeunga et al. (2008), Shiferaw et al. (2010), Thuo et al. (2014) and Mwalongo et al. (2020).

\section{Conclusions and Recommendations}

The study offers useful insights into factors influencing the adoption decisions of farmers and provides convenient feedback to the researchers as well as the policymakers. Groundnut has large yield potential in the Pothwar region of Punjab, but its actual production is far below the potential level. Most of the farmers were adhered to the cultivation of local varieties of groundnut crop due to various reasons. The study finds that the major challenges in the adoption of improved groundnut varieties in the study area include: farmers' conventional behavior in the choice of varieties, lack of farmers' awareness, non-availability of reliable seed, and lack of promotion of improved varieties of groundnut in the market. However, according to the study results, improved varieties are found more responsive towards the use of farm inputs as compared to the conventional varieties.

It is suggested that government should take concrete measures for the production and accessibility of reliable seed of improved groundnut varieties. There should be an advancement in the institutional arrangements that could deliver certified seed at affordable costs to the farmers. The private donors may also be motivated to invest for enhancement in the adoption of improved agricultural technology in the national cause. The farmer's attitude is to be changed from conventional and subsistent farming towards the modernized and profit-oriented agribusiness. Agriculture Extension Department and Punjab Seed Corporation, in collaboration with different research institutes, may promote the improved varieties in the best farmer's interest.

\section{Acknowledgments}

The authors wish to thank Mr. Muhammad Aslam, Deputy Director (Agri. Extension), Chakwal, Punjab, and Mr. Zia-Ur-Rehman, Agriculture Officer (Agriculture Extension), Chakwal, Punjab for providing the information about groundnut growing farmers and assisting in data collection.

\section{Novelty Statement}

The paper makes a valuable contribution to the existing literature vis-à-vis the choice of improved agricultural technologies by the farming community and, specifically, understanding the reasons of low adoption rate of improved ground varieties in Pakistan.

\section{Authors' Contribution}

Khalid Mehmood: Designed and conducted research, data collection, analysis and wrote draft of the manuscript.

Abdul Rehman: Wrote original draft and Methodology.

Ammara Khan: Formal analysis and investigation, data collection and revision of the manuscript for final submission

\section{Conflicts of Interest}

The authors declare no conflicts of interest. 


\section{References}

Aldrich, J.H., Nelson, F.D. and Adler, E.S. 1984. Linear probability, logit, and probit models: Sage. https://doi.org/10.4135/9781412984744

BARI. 2020. Production technology of groundnut: Barani Agricultural Research Institute, Chakwal. https://barichakwal.punjab.gov.pk/system/ files/GROUNDNUT-BARI.pdf

Daudi, H., Shimelis, H., Laing, M., Okori, P. and Mponda, O. 2018. Groundnut production constraints, farming systems, and farmer-preferred traits in Tanzania. J. Improv. 32(6): 812-828. https://doi.org/10.1080/15427528.2018.15318 01

de Janvry, A. 1972. The generalized power production function. Am. J. Agric. Econ. 54(2): 234237. https://doi.org/10.2307/1238706

Debertin, D.L. 2012. Agricultural production economics (2nd ed.). New York, USA: Macmillan Publishing Company. Pp. 14-37.

DeMaris, A. 1992. Logit modeling: Practical applications (Vol. 86): Sage. https://doi. org/10.4135/9781412984836

Freeman, H., Van der Merwe, P., Subrahmanyam, P., Chiyembekeza, A. and Kaguongo, W. 2002. Assessing adoption potential of new groundnut varieties in Malawi. https://doi.org/10.1017/ S0014479702000261

GoP. 2017. Population Census 2017. Pakistan Bureau of Statistics, Government of Pakistan Islamabad: Pakistan, Islamabad, 2018.

Griffiths, W.E., Hill, R.C. and Judge, G.G. 1993. Learning and practicing econometrics. John Willey and Sons. Inc. New York, USA.

Gujarati, D.N. 2009. Basic econometrics: Tata McGraw-Hill Education.

Halter, A.N., Carter, H. and Hocking, J. 1957. A note on the transcendental production function cx 1 a 1 e b 1 x 1 x 2 a 2 e b 2 x 2 . J. farm Econ. 966-974. https://doi.org/10.2307/1234207

Hussain, M., Ali, A., Masood, S., Saadia, Afzal, S., Afzal, A. and Ali, Q. 2020. Evaluation of optimum sowing dates for newly developed lines of groundnut in Rainfed areas of northern Punjab. Int. J. Bot. Stud. 5(1): 58-61.

Hussein, H.A.A., Darwesh, O.M., Mekki, B.B. and E1-Hallouty, S.M. 2019. Evaluation of cytotoxicity, biochemical profile and yield components of groundnut plants treated with nano-selenium. Biotechnol. Rep. 24: e00377. https://doi. org/10.1016/j.btre.2019.e00377

Ibrahim, M., Florkowski, W.J. and Kolavalli, S. 2012. Determinants of Farmer Adoption of Improved Peanut Varieties and their Impact on Farm Income: Evidence from Northern Ghana. Jelliffe, J.L., Bravo-Ureta, B.E., Deom, C.M. and Okello, D.K. 2018. Adoption of high-yielding groundnut varieties: The sustainability of a farmer-led multiplication-dissemination program in Eastern Uganda. Sustainability. 10(5): 1597. https://doi.org/10.3390/su10051597

Kassie, M., Shiferaw, B. and Muricho, G. 2010. Adoption and impact of improved groundnut varieties on rural poverty: evidence from rural Uganda. Environment for Development Discussion Paper-Resources for the Future (RFF). 10-11.

Konja, D.T., Mabe, F.N. and Oteng-Frimpong, R. 2019. Profitability and profit efficiency of certified groundnut seed and conventional groundnut production in Northern Ghana: A comparative analysis. Cogent Econ. Finance. 7(1): 1631525. https://doi.org/10.1080/23322039.2 019.1631525

Malik, M.U., Javed, H. and Ayyaz, M. 2015. Evaluation of different groundnut Arachis hypogea L. cultivars against termites, Odontotermes obesus (Rambur) in Rawalpindi, Pakistan. Turkish J. Agric. Food Sci.Technol.3(6): 448-452. https:// doi.org/10.24925/turjaf.v3i6.448-452.235

Marshall, C. and Rossman, G.B. 2014. Designing qualitative research ( $6^{\text {th }}$ ed.): Sage publications, London, UK.

Mwalongo, S., Akpo, E., Lukurugu, G.A., Muricho, G., Vernooy, R., Minja, A. and Varshney, R. 2020. Factors influencing preferences and adoption of improved groundnut varieties among farmers in Tanzania. Agron. 10(9): 1271. https://doi.org/10.3390/agronomy10091271

Naeem-Ud-Din, Abid, M., Khattak, G., Iqbal, S. and Hassan, M. 2009. High yielding groundnut (Arachis hypogea L.) variety" Golden". Pak. J. Bot. 41(5): 2217-2222.

Ndjeunga, J., Ntare, B., Waliyar, F., Echekwu, C., Kodio, O., Kapran, I. and Da Sylva, A. 2008. Early adoption of modern groundnut varieties in West Africa Working Paper Series No. 24 Socio Economic and Policy.

PARC. 2020. Production Technology of Groundnut: Pakistan Agricultural Research Council, Islamabad. http://www.parc.gov. 
pk/index.php/en/137-narc/crop-sciencesinstitue/728-groundnut

Pasupuleti, J., Nigam, S., Pandey, M.K., Nagesh, P. and Varshney, R.K. 2013. Groundnut improvement: use of genetic and genomic tools. Front. Plant Sci. 4: 23. https://doi.org/10.3389/ fpls.2013.00023

Rajpar, H., Zhang, A., Razzaq, A., Mehmood, K., Pirzado, M.B. and Hu, W. 2019. Agricultural Land Abandonment and Farmers' Perceptions of Land Use Change in the Indus Plains of Pakistan: A Case Study of Sindh Province. Sustainability. 11(17): 4663. https://doi.org/10.3390/ su11174663

Shah, H., Khan, M.A., Azeem, T., Majid, A. and Mehmood, A. 2012. The Impact of gypsum application on groundnut yield in rainfed Pothwar: An Economic Perspective. Lahore J. Econ. 17(1). https://doi.org/10.35536/lje.2012.v17. i1.a5

Sheirdil, R.A., Mahmood, A., Khan, R.U., Khalid, R. and Amara, U. 2012. Groundnut; a crop for subsistence in edible oil production in Pakistan.
Agrihunt. Retrieved October, 30, 2013.

Shiferaw, B., Muricho, G., Okello, J., Kebede, T. and Okecho, G. 2010. Adoption of improved groundnut varieties in Uganda.

Simtowe, F., Kassie, M., Asfaw, S., Shiferaw, B.A., Monyo, E. and Siambi, M. 2012. Welfare Effects of Agricultural Technology adoption: the case of improved groundnut varieties in rural Malawi.

Tanellari, E., Kostandini, G., Bonabana-Wabbi, J. and Murray, A. 2014. Gender impacts on adoption of new technologies: the case of improved groundnut varieties in Uganda. Afr. J. Agric. Resour. Econom. 9(311-2016-5619); 300-308.

Team, R.C. 2020. Vienna, Austria Patent No. R Foundation for Statistical Computing.

Thuo, M., Bell, A.A., Bravo-Ureta, B.E., Lachaud, M.A., Okello, D.K., Okoko, E.N. and Puppala, N. 2014. Effects of social network factors on information acquisition and adoption of improved groundnut varieties: the case of Uganda and Kenya. Agric. Hum. Values, 31(3): 339-353. https://doi.org/10.1007/s10460-014-9486-6 